\title{
CLINICO-PATHOLOGICAL STUDY OF CUTANEOUS TUMOURS OF HEAD \& NECK
}

\author{
Vidhya Chellamaiahㅁ, Vijayalakshmi B2, K. Manoharan ${ }^{3}$ \\ ${ }^{1}$ Assistant Professor, Institute of Venereology, Madras Medical College and RGGGH. \\ ${ }^{2}$ Senior Assistant Professor, Department of Dermatology, Madras Medical College and RGGGH. \\ ${ }^{3}$ Former Professor and HOD, Department of Dermatology, Madras Medical College and RGGGH.
}

\section{ABSTRACT}

\section{BACKGROUND}

Skin is a complex \& the largest organ in the body. Because of its complexity, a range of disease can develop from skin including tumors, which are more difficult to define than when found elsewhere.

Aim is to study the overall frequency, age \& sex distribution, different clinical presentation \& histopathological features of various skin tumours confined to head \& neck.

\section{MATERIALS \& METHODS}

It is a descriptive study of 100 patients selected at random presenting with different forms of cutaneous tumours of head \& neck attending Skin and STD OP, Chengalpet Government Hospital, Chengalpet for a period of one year. Clearance was obtained from Ethical Committee.

\section{RESULTS}

Out of 100 patients, 46 were males and 54 were females. Majority of the patients were in the age group of fifth decade (23\%) \& sixth decade (21\%). Mostly were benign tumours (88\%). Commonest skin tumours were surface tumours of epidermis (62\%) especially Acrochordons (15\%) \& seborrheic keratosis (14\%) followed by tumours of epidermal appendages (21\%) with classical histopathology. Familial occurrence was noted in 2 cases of syringoma, 2 cases of steatocystoma multiplex and one case of keloid. Rare case like xeroderma pigmentosum with squamous cell carcinoma was encountered in a female child.

\section{CONCLUSION}

Most of the skin tumours of head \& neck whether benign or malignant though symptomless, they were cosmetically unacceptable \& were treated accordingly. Hence, by correlating the clinical and histopathological features, a definitive diagnosis can be established.

\section{KEYWORDS}

Head \& Neck Cutaneous Tumours, Skin Tumours.

HOW TO CITE THIS ARTICLE: Chellamaiah V, Vijayalakshmi B, Manoharan K. Clinico-pathological study of cutaneous tumours of head \& neck. J. Evolution Med. Dent. Sci. 2017;6(3):238-244, DOI: 10.14260/Jemds/2017/55

\section{BACKGROUND}

Tumours of skin are histopathologically diverse group of entities which have common localized proliferation of cells resulting in clinically discrete lesions. They may be divided into a number of categories, reflecting their different biological behaviour. These include hamartomas, benign tumours, premalignant and malignant conditions. This study is based on the classification of tumours of skin given in the LEVERS Histopathology of skin $10^{\text {th }}$ edition and Seldon \& Helwig, 1974 approved by WHO(1) are given below \& this study is confined to the head and neck.

- Tumours of surface epidermis.

- Tumours of epidermal appendages.

- Tumours of the fibrous tissues.

- Tumours of the vascular tissues.

- Tumours of the fatty, muscular and osseous tissue.

- Tumours of the neural tissue.

- Disorders of nevus cells and melanocytes.

Financial or Other, Competing Interest: None.

Submission 03-12-2016, Peer Review 28-12-2016,

Acceptance 04-01-2017, Published 09-01-2017.

Corresponding Author:

Dr. Vidhya Chellamaiah,

Assistant Professor, Institute of Venereology,

Madras Medical College and RGGGH,

E-mail: vidhyalivingston@gmail.com

DOI: $10.14260 /$ jemds $/ 2017 / 55$

\section{MATERIALS AND METHODS}

It is a descriptive study of 100 patients presenting with different forms of cutaneous tumours of head \& neck, attending Skin and STD OP, Chengalpet Government Hospital, Chengalpet for a period of one year. Informed consent was obtained. A detailed history including demographic data, chief complaints related to skin, onset and duration of disease and associated medical or skin disorders was elicited and recorded. Specific and relevant histories including family history, history of medical and surgical intervention for the above complaints were also taken from certain cases with skin tumours. Thorough clinical examination of the skin lesions was carried out in all the cases with reference to the site, number, size, shape, colour, surface, borders, consistency, tenderness and compressibility of the lesions. Whether the lesions were grouped or discrete, sessile or pedunculated or whether there were any attachment to the underlying structures or the overlying skin were also observed.

Careful general and systemic examinations were carried out. Investigations like complete haemogram, blood sugar, renal function test, VDRL, HIV status and skin biopsy in the form of both excision and incision biopsy were carried out. The sections for histopathological examination were stained with haematoxylin and eosin and studied in both low and high power magnifications. 


\begin{tabular}{|c|c|c|c|}
\hline $\begin{array}{c}\text { Sl. } \\
\text { No. }\end{array}$ & Classification & $\begin{array}{c}\text { No. of } \\
\text { Cases }\end{array}$ & $\mathbf{\%}$ \\
\hline 1 & Tumours of surface epidermis & 62 & 62 \\
\hline 2 & $\begin{array}{c}\text { Tumours of epidermal } \\
\text { appendages }\end{array}$ & 21 & 21 \\
\hline 3 & $\begin{array}{c}\text { Tumours of the fibrous } \\
\text { tissues }\end{array}$ & 5 & 5 \\
\hline 4 & $\begin{array}{c}\text { Tumours of the vascular } \\
\text { tissues }\end{array}$ & 4 & 4 \\
\hline 5 & $\begin{array}{c}\text { Tumours of the fatty, } \\
\text { muscular and osseous tissue }\end{array}$ & - & - \\
\hline 6 & Tumours of the neural tissue & 8 & 8 \\
\hline 7 & $\begin{array}{c}\text { Disorders of nevus cells and } \\
\text { melanocytes }\end{array}$ & - & - \\
\hline \multicolumn{2}{|c|}{ TOTAL } & $\mathbf{1 0 0}$ & $\mathbf{1 0 0 \%}$ \\
\hline Table 1. Incidence of Various Types of Skin Tumours \\
\hline \multicolumn{2}{|c|}{}
\end{tabular}

\begin{tabular}{|c|c|c|c|c|}
\hline $41-50$ & 11 & 12 & 23 & 23 \\
\hline $51-70$ & 7 & 14 & 21 & 21 \\
\hline Total & 46 & 54 & 100 & 100 \\
\hline
\end{tabular}

\begin{tabular}{|c|c|c|c|c|}
\hline $\begin{array}{c}\text { Age Group } \\
\text { (yrs) }\end{array}$ & \multicolumn{2}{|c|}{ No. of Cases } & \multirow{2}{*}{ Total } & \multirow{2}{*}{ Percentage } \\
\cline { 2 - 3 } & $\mathbf{M}$ & $\mathbf{F}$ & & 2 \\
\hline Birth-10 year & 1 & 1 & 2 & 15 \\
\hline $11-20$ & 9 & 6 & 15 & 20 \\
\hline $21-30$ & 11 & 9 & 20 & 19 \\
\hline $31-40$ & 7 & 12 & 19 & \\
\hline
\end{tabular}

\begin{tabular}{|c|c|c|c|}
\hline List of Skin Tumours & Male & Female & Nos. \\
\hline Seborrhoeic keratosis & 8 & 6 & 14 \\
\hline Acrochordons & 8 & 7 & 15 \\
\hline Epidermal nevus & 2 & 4 & 6 \\
\hline Basal cell carcinoma & 2 & 5 & 7 \\
\hline Squamous cell carcinoma & 2 & 3 & 5 \\
\hline Epidermal cysts & 8 & 4 & 12 \\
\hline Steatocystoma multiplex & 2 & 1 & 3 \\
\hline Trichoepithelioma & 2 & 3 & 5 \\
\hline Nevus sebaceous & 3 & 1 & 4 \\
\hline Syringoma & 2 & 10 & 12 \\
\hline Keloid & 1 & 2 & 3 \\
\hline Angiofibroma & 1 & 1 & 2 \\
\hline Pyogenic granuloma & 1 & 3 & 4 \\
\hline Neurofibroma & 4 & 4 & 8 \\
\hline TOTAL & $\mathbf{4 6}$ & $\mathbf{5 4}$ & $\mathbf{1 0 0}$ \\
\hline Table 3. List of skin tumours as in 100 patients \\
\hline \multicolumn{4}{|l}{}
\end{tabular}

\begin{tabular}{|c|c|c|c|c|c|c|c|c|c|c|c|c|c|c|c|}
\hline 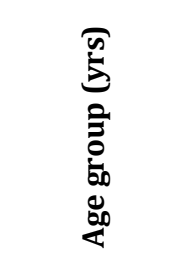 & 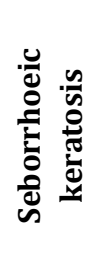 & 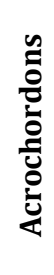 & 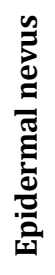 & U্ & U & 氶 & 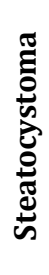 & 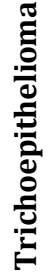 & 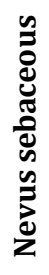 & 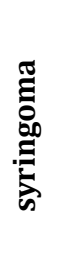 & 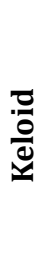 & 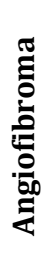 & 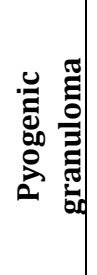 & 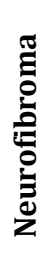 & 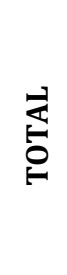 \\
\hline Birth-10 year & - & - & 2 & - & - & - & - & - & - & - & - & - & - & - & 2 \\
\hline $11-20$ & - & - & 3 & - & 1 & 4 & - & - & 2 & 1 & - & 2 & 1 & 1 & 15 \\
\hline $21-30$ & - & 1 & 1 & - & - & 2 & 2 & 3 & 2 & 3 & 1 & - & 2 & 3 & 20 \\
\hline $31-40$ & - & 4 & - & - & - & 2 & - & 2 & - & 6 & 2 & - & - & 3 & 19 \\
\hline $41-50$ & 6 & 7 & - & 3 & - & 3 & 1 & - & - & 1 & - & - & 1 & 1 & 23 \\
\hline $51-70$ & 8 & 3 & - & 4 & 4 & 1 & - & - & - & 1 & - & - & - & - & 21 \\
\hline Total & 14 & 15 & 6 & 7 & 5 & 12 & 3 & 5 & 4 & 12 & 3 & 2 & 4 & 8 & 100 \\
\hline
\end{tabular}

\section{RESULTS}

Of 100 patients studied, 46 were males and 54 were females. Majority of the patients reported with the skin tumours of head and Neck were adults in the age group of fifth decade (23\%) followed by sixth \& seventh decade (21\%). The commonest skin tumours recorded were surface tumours of epidermis $(62 \%)$ followed by tumours of epidermal appendages $(21 \%)$, tumours of neural tissue $(8 \%)$ \& other tumours constitute (9\%). Mostly were benign (88\%) except basal cell \& squamous cell carcinoma which constitutes $12 \%$. The commonest tumour encountered in this study was Acrochordons (15\%) with classical histopathology. The second common tumour was seborrhoeic keratosis (14\%). Epidermal cyst and syringoma (12\%) were the third most common tumour encountered in this study. Neurofibroma (8\%), Basal cell carcinoma (7\%), Epidermal nevus (6\%), squamous cell carcinoma (5\%), trichoepithelioma (5\%), pyogenic granuloma (4\%), nevus sebaceous (3\%), steatocystoma multiplex (3\%), keloid (3\%), angiofibroma (2\%) were also encountered in our study with classical clinical and histopathological findings. Rare case like xeroderma pigmentosum with squamous cell carcinoma was encountered in a female child. In this study, among 15 patients with acrochordons, 6(40\%) had diabetes mellitus. Familial occurrence was noted in 2 cases of syringoma, 2 cases of steatocystoma multiplex and one case of keloid.

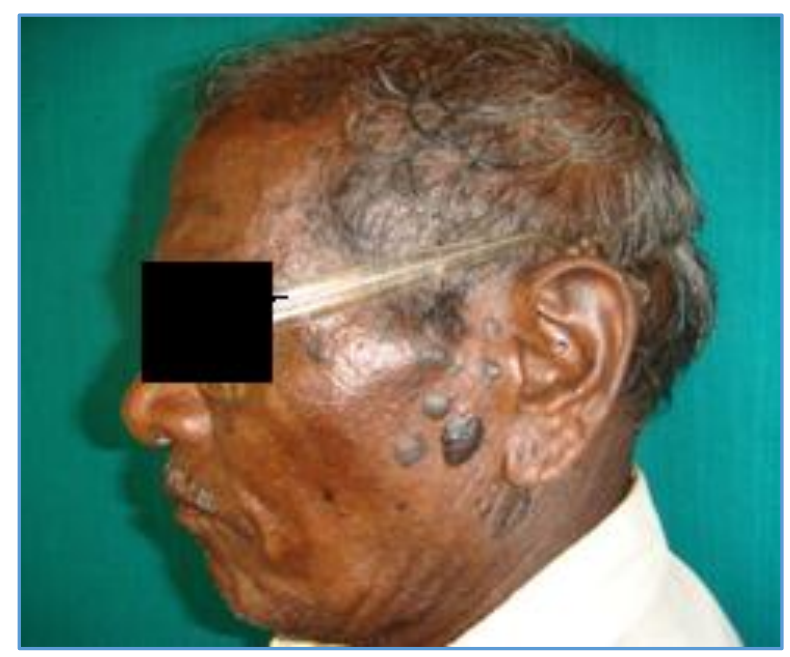

Figure 1(a). Seborrhoeic keratosis over the face 


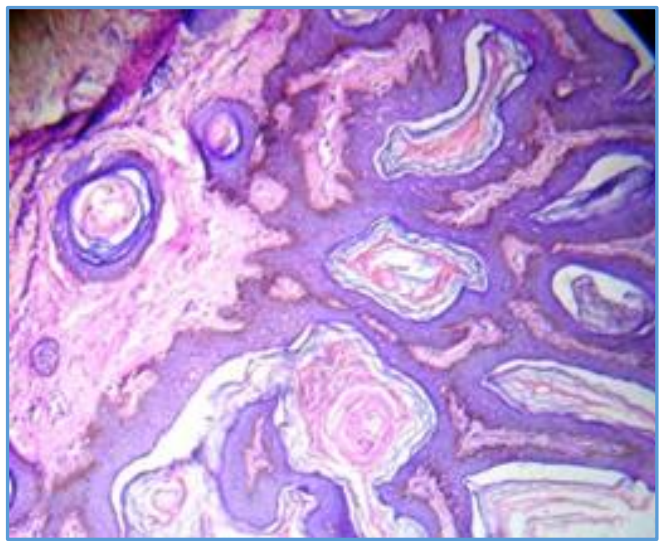

Figure 1(b). Histopathology of seborrhoeic keratosis showing horn cysts.

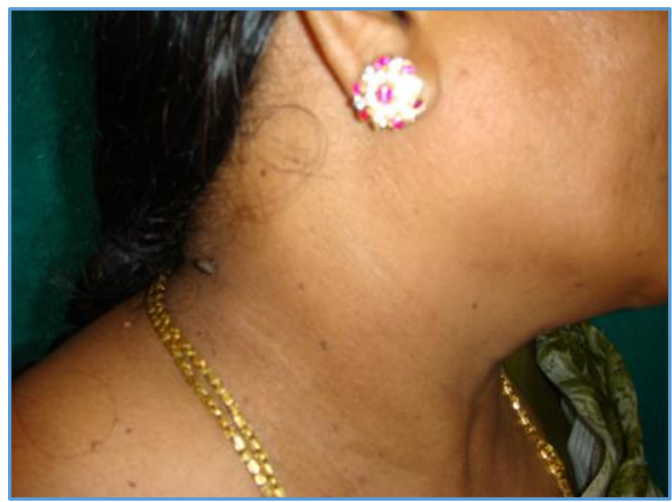

Figure 2(a). Multiple skin tags (both sessile \& pedunclated) over the neck.

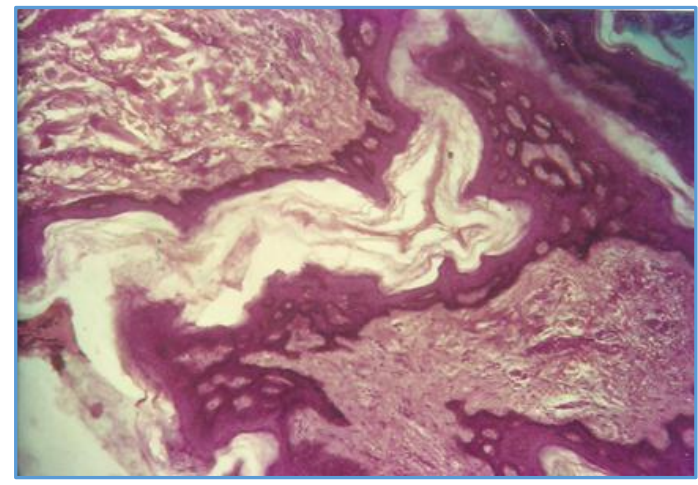

Figure 2(b). Histopathology of Acrochordons with proliferation of fibrocollagenous tissue.

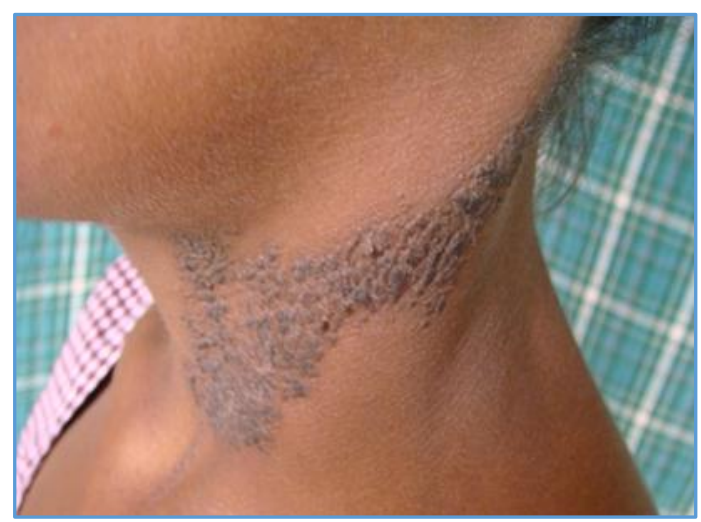

Figure 3(a). Epidermal nevus over the side of neck

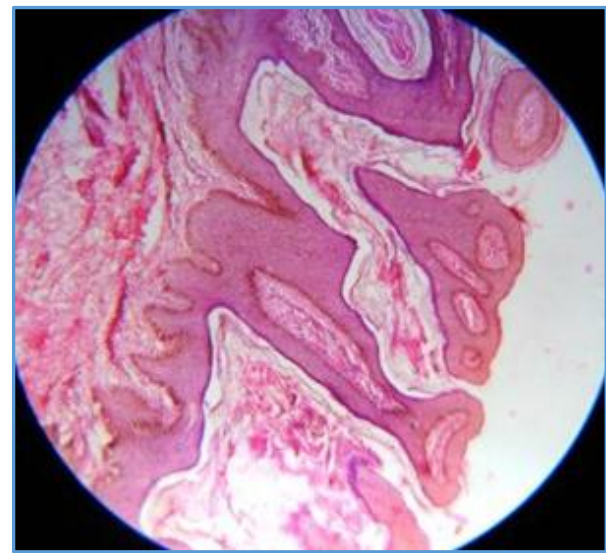

Figure 3(b). Histopathology of epidermal nevus showing hyperkeratosis, acanthosis and papillomatosis

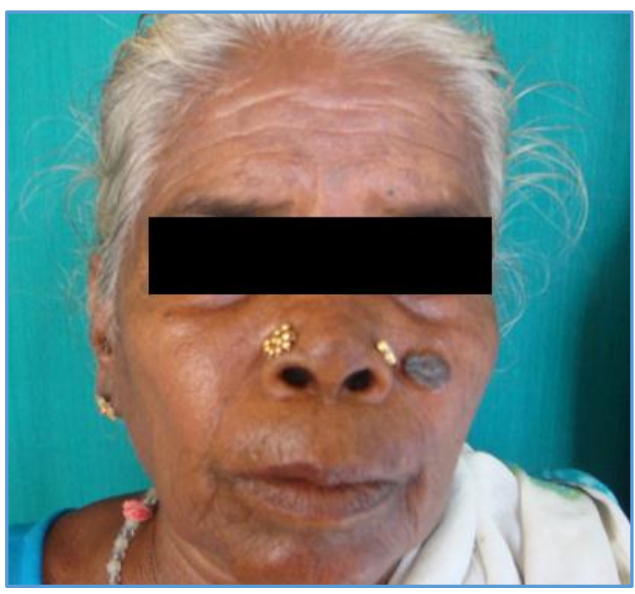

Figure 4(a). Noduloulcerative basal cell carcinoma over the face

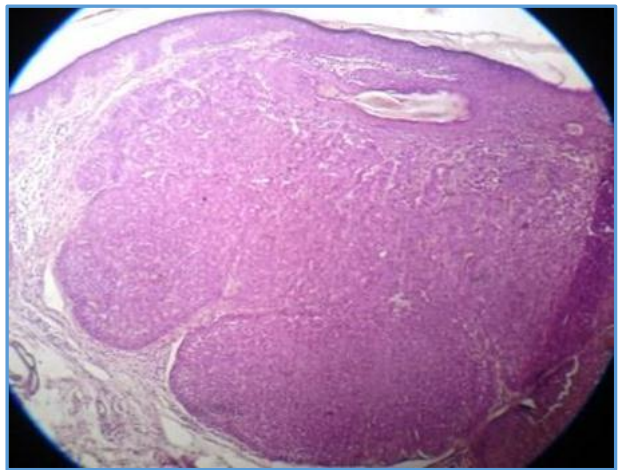

Figure 4(b). Histopathology of basal cell carcinoma showing islands of tumour cells with Peritumoral lacuna

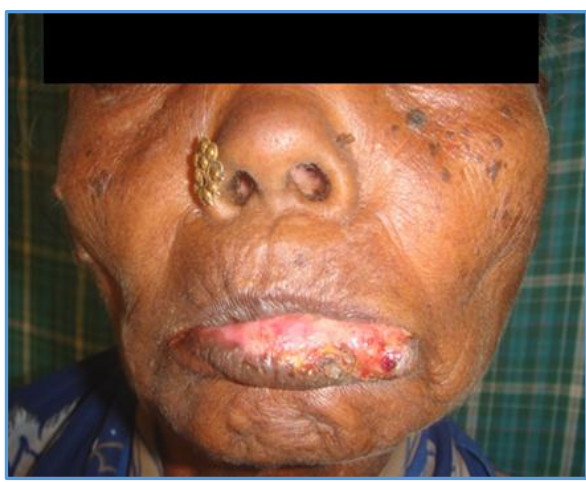

Figure 5(a). Squamous cell carcinoma in the lower lip 


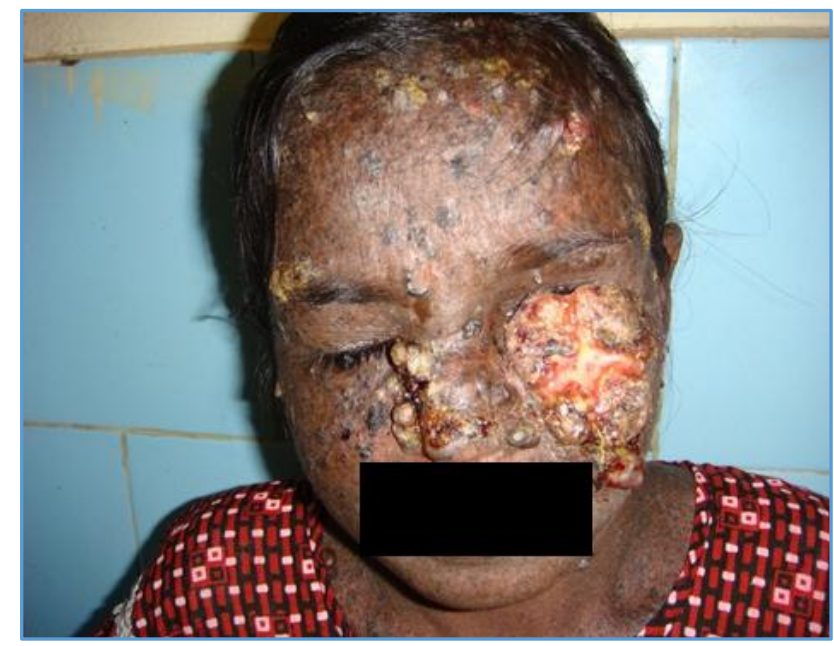

Figure 5(b). Xeroderma pigmentosum with squamous cell carcinoma over the face

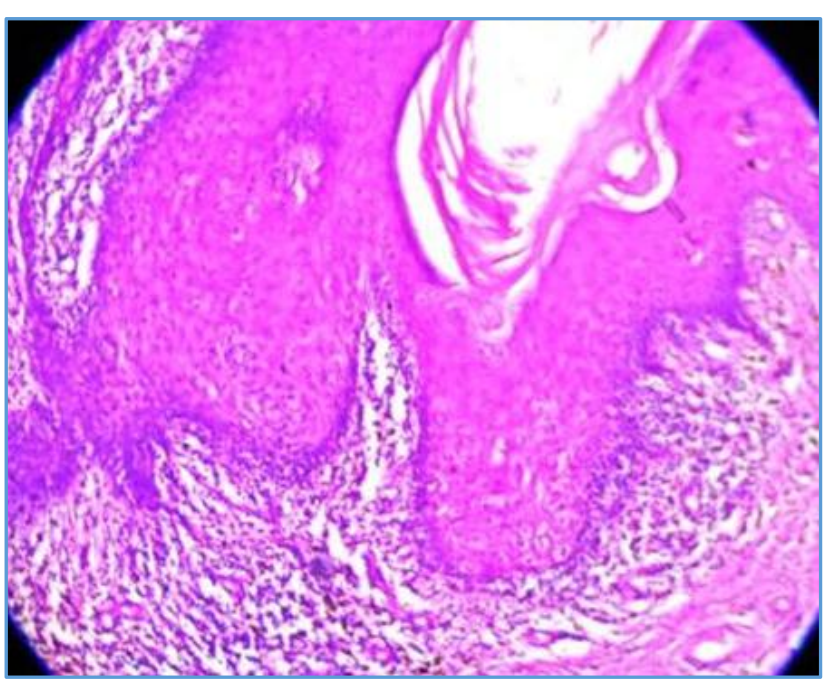

Figure 5(c). Histopathology of squamous cell carcinoma shows massive hyperplasia

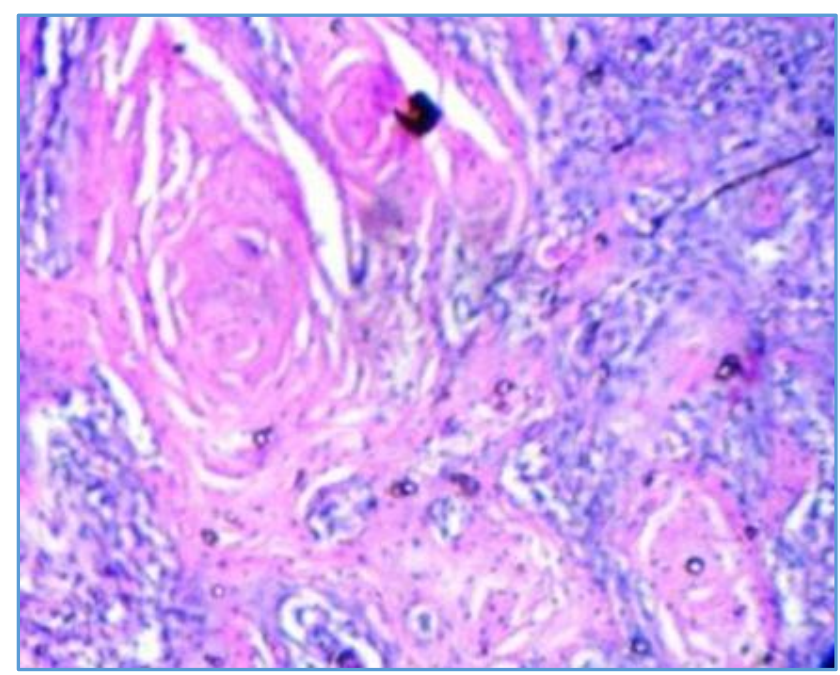

Figure 5(d). Histopathology of squamous cell carcinoma shows horn pearls.

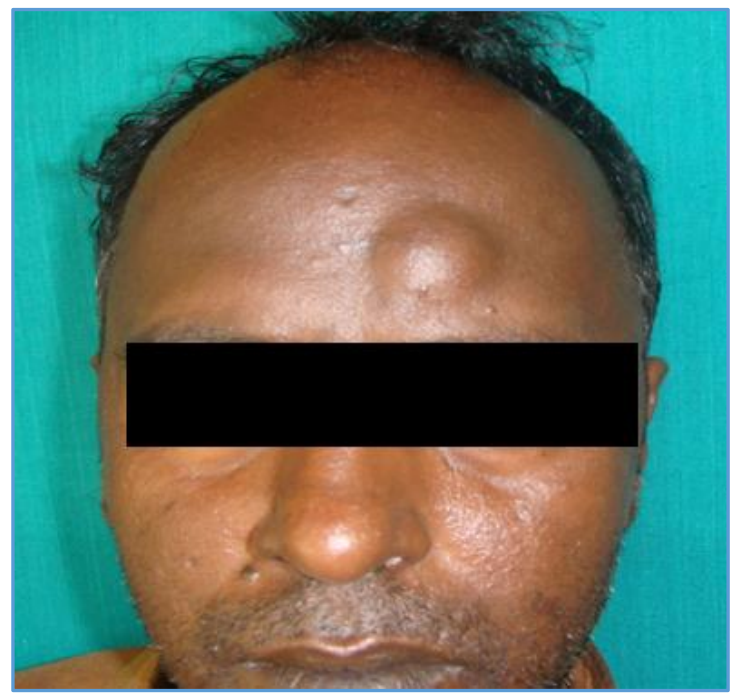

Figure 6(a). Epidermal cyst over the scalp

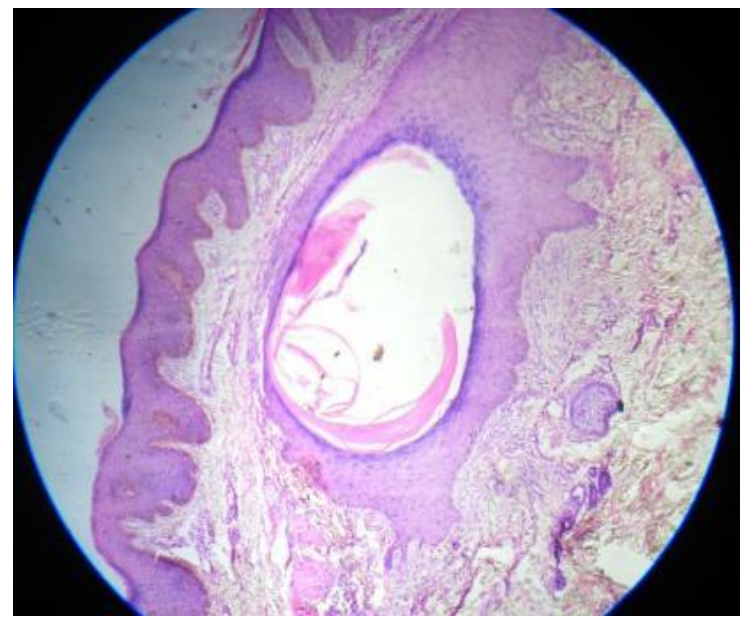

Figure 6(b). Histopathology of epidermal cyst with keratin in the cavity

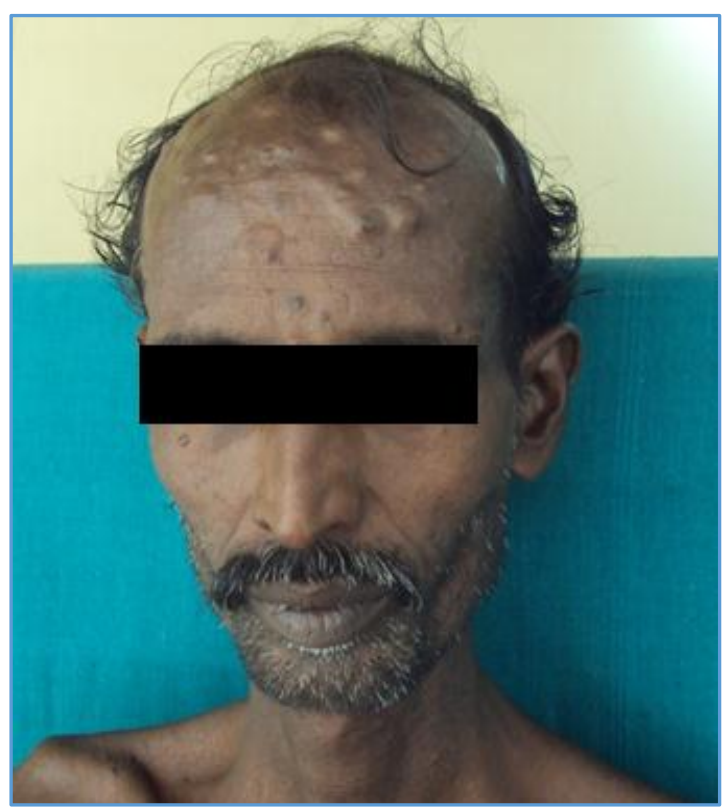

Figure 7(a). Steatocystoma multiplex over the neck and chest 


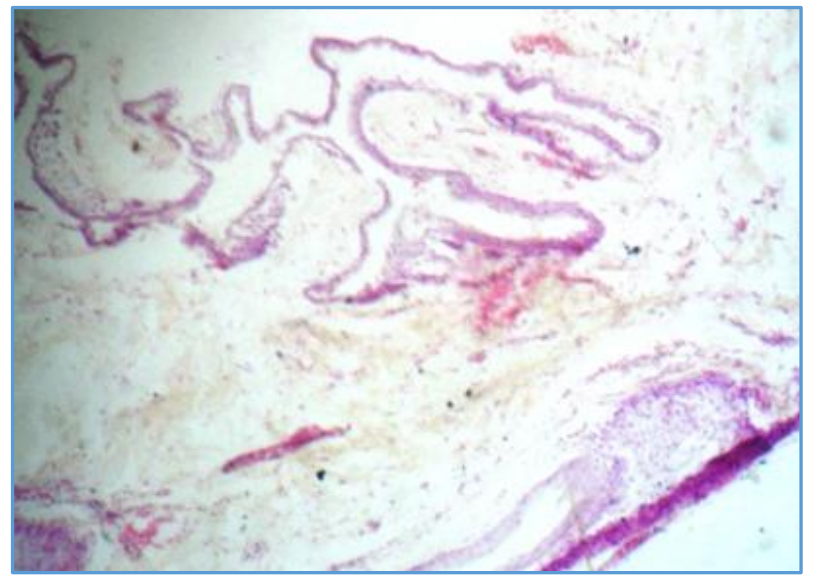

Figure 7(b). Histopathology of the steatocystoma multiplex showing intricately folded cyst

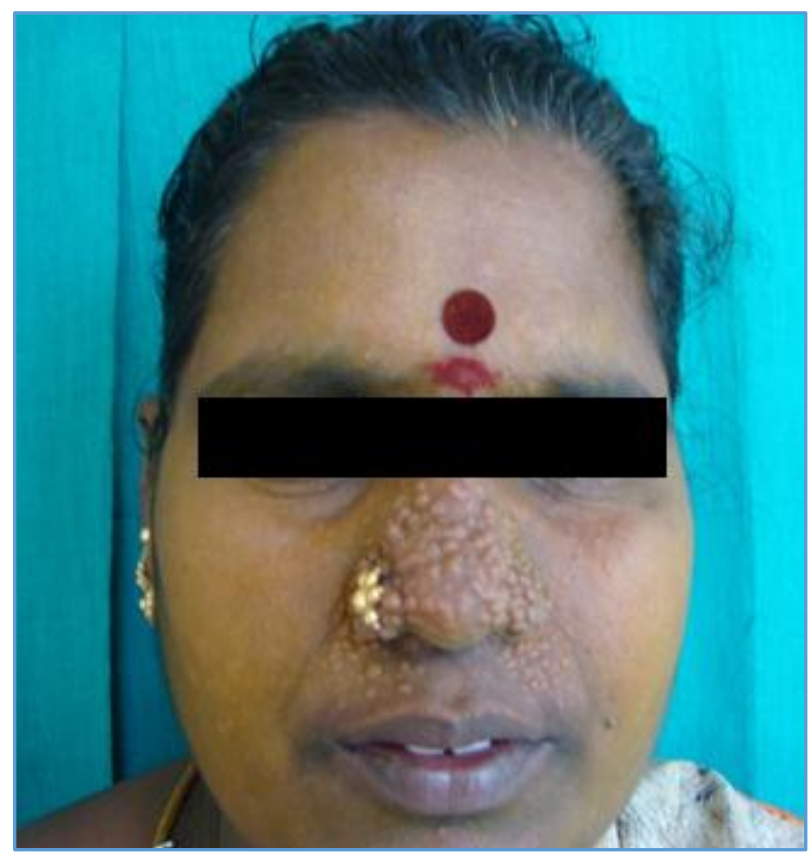

Figure 8(a) Multiple trichoepithelioma of the face

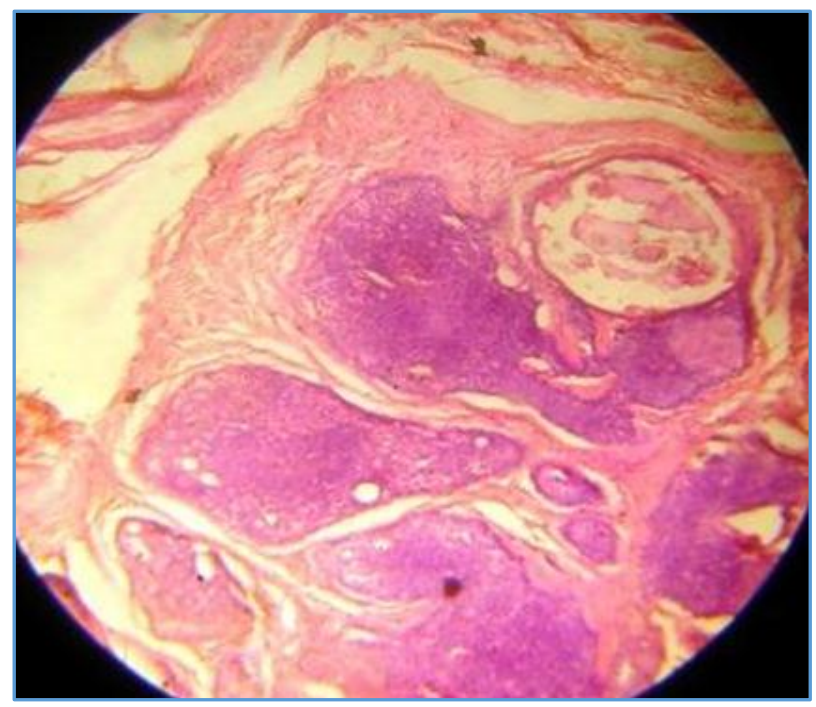

Figure 8(b). Histopathology of trichoepithelioma shows basaloid cells and horn cysts

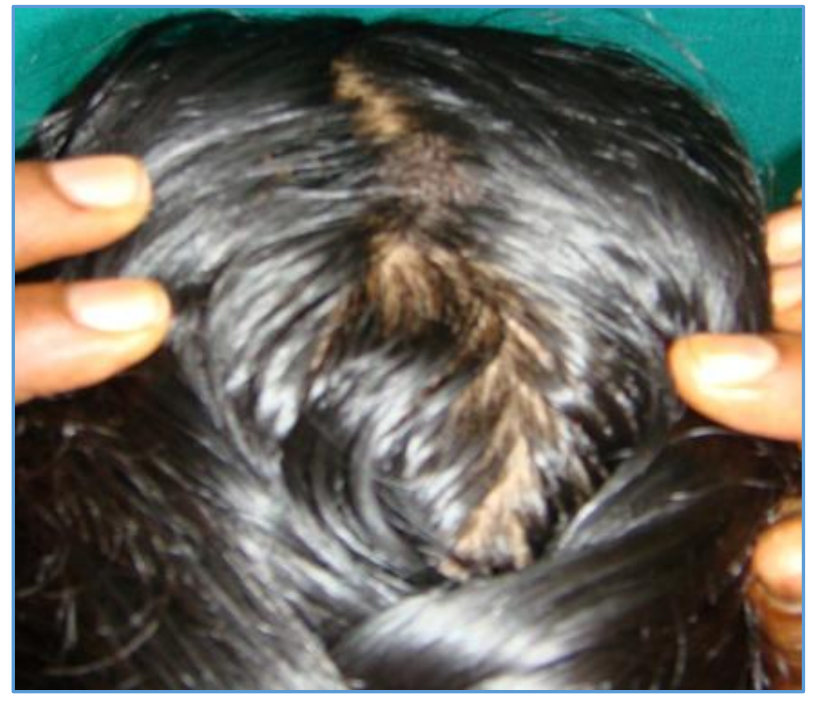

Figure 9(a) Nevus sebaceous of the scalp

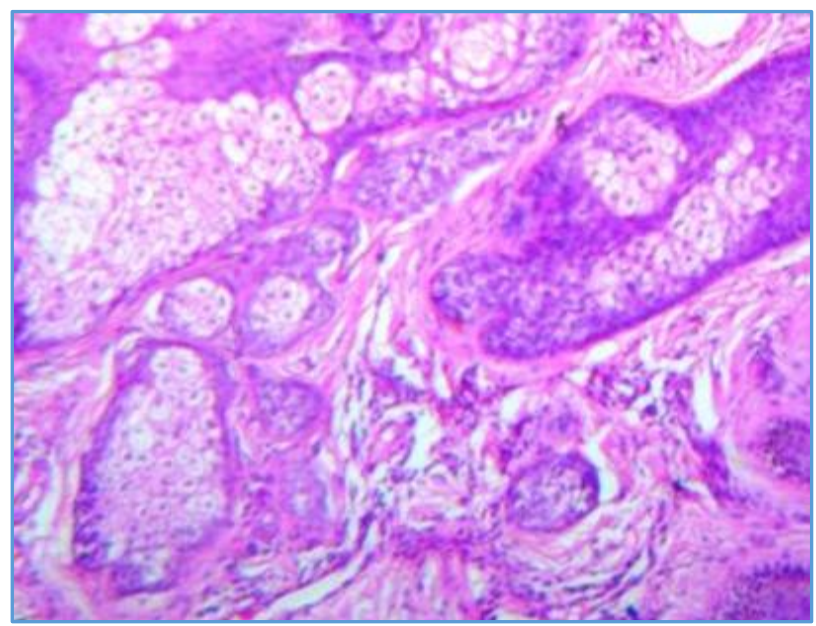

Figure 9(b) - Histopathology of nevus sebaceous shows proliferation of mature sebaceous glands

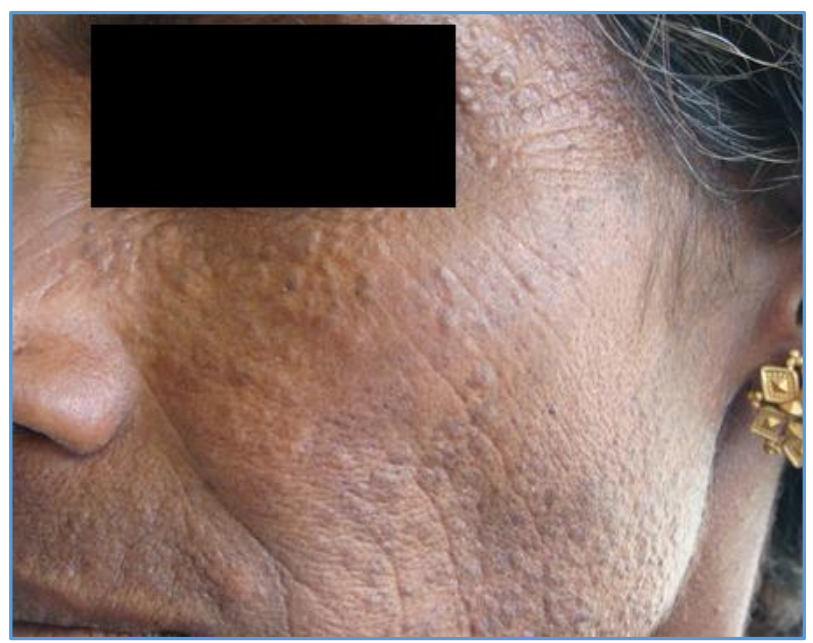

Figure 10(a). Syringoma of the infra orbital region 


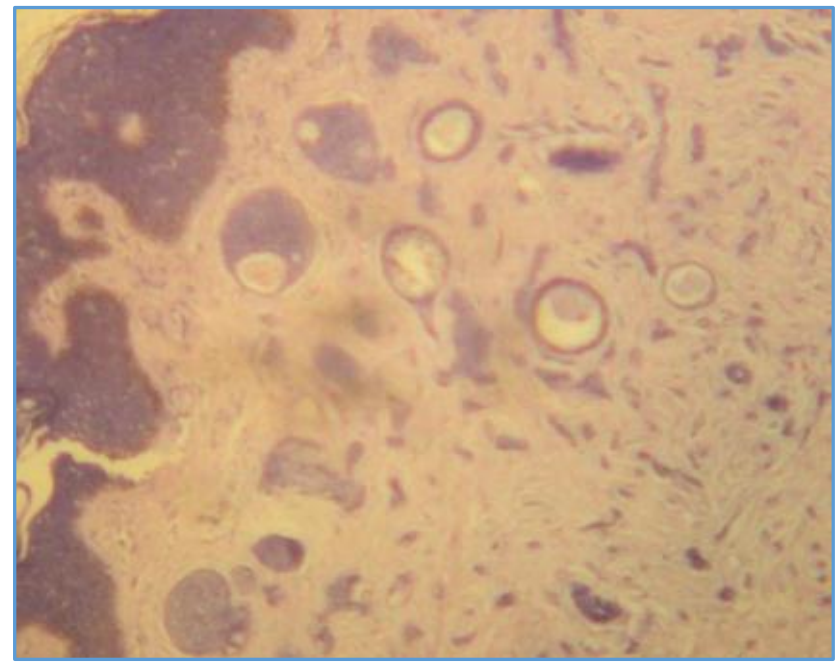

Figure 10(b). Histopathology of syringoma shows numerous cystic ductal structures in the stroma. Some of the ducts show tadpole appearance

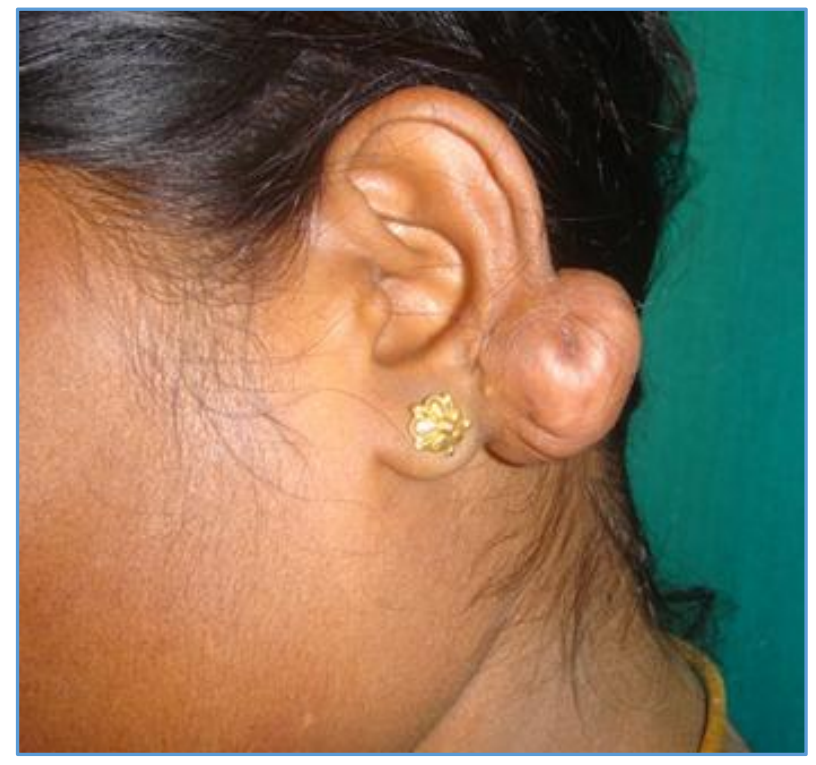

Figure 11(a). Keloid over the left ear

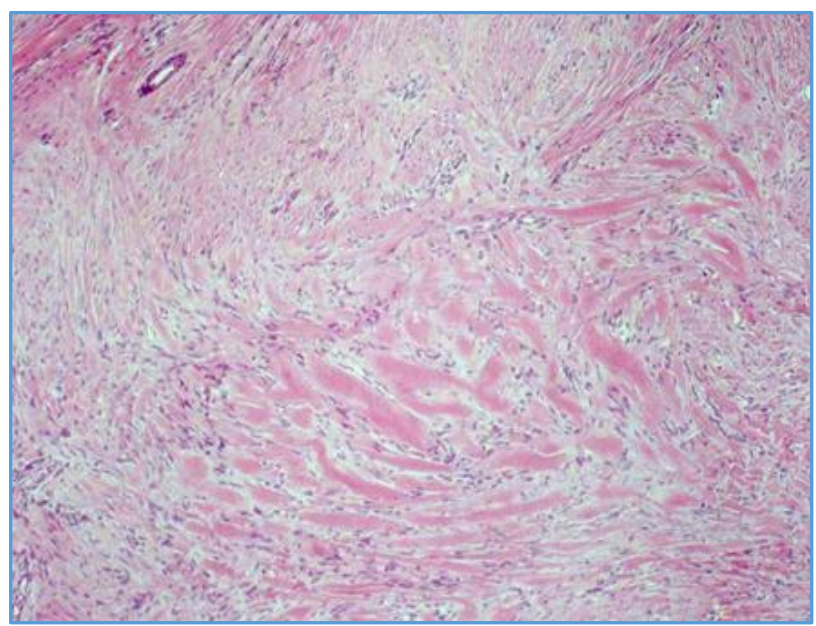

Figure 11(b)-Histopathology of keloid demonstrating thick hyalinised collagen bundles

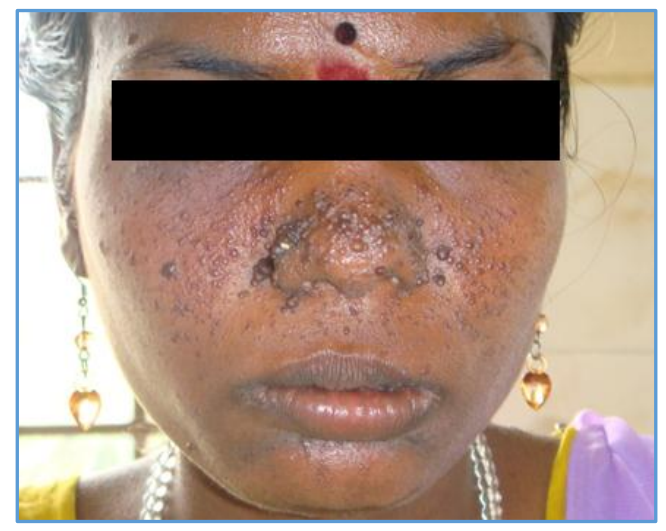

Figure 12(a). Facial Angiofibroma in a patient of Tuberous sclerosis.

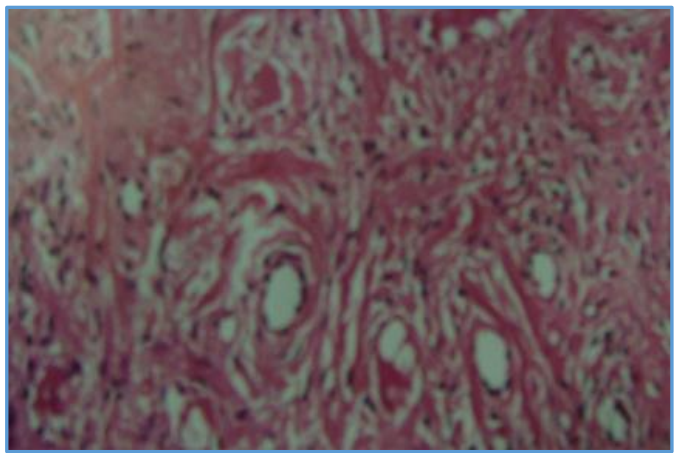

Figure 12(b). Histopathology of Angiofibroma showing sclerotic, hyalinized collagenous stroma surrounding the telangiectatic blood vessels.

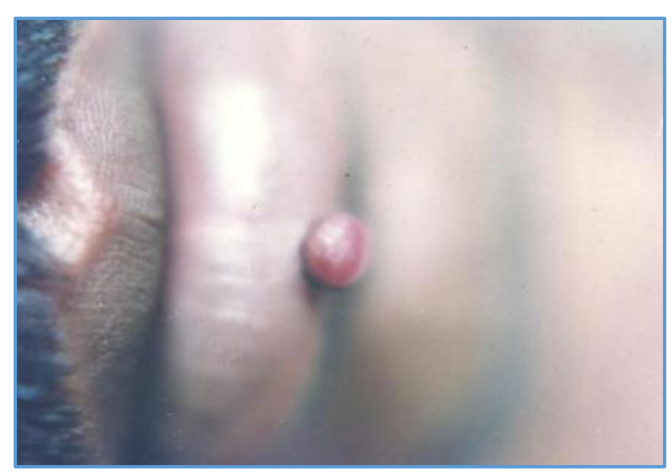

Figure 13(a). Granuloma pyogenicum over the lower lip

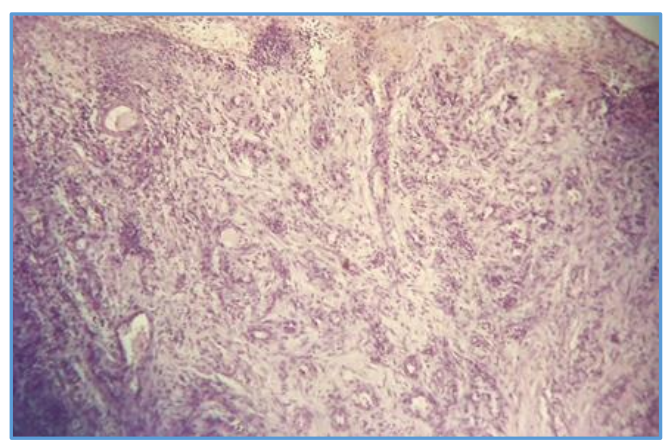

Figure 13(b). Histopathology of Granuloma pyogenicum showing the lobules of proliferated capillaries 


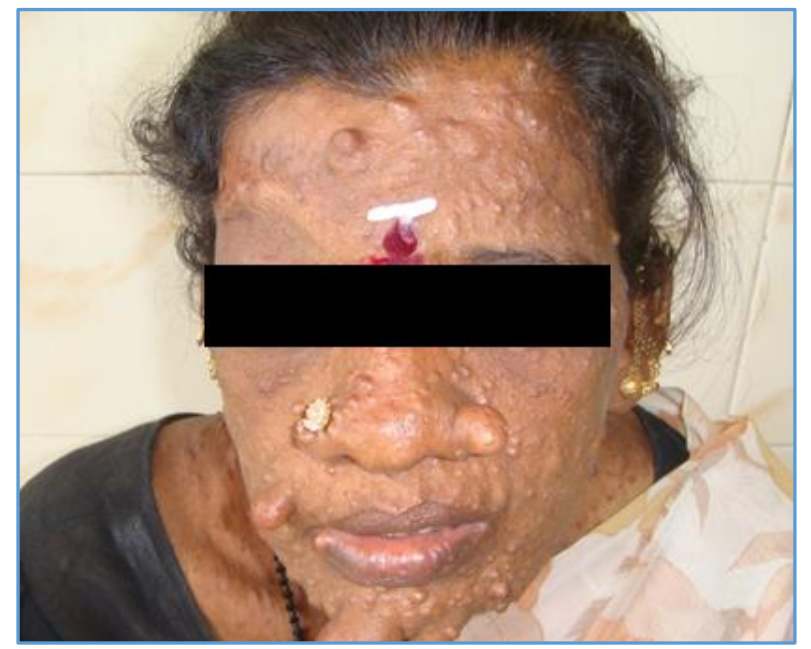

Figure 14(a). Multiple Neurofibromas over the face. Note the Café -au lait macules

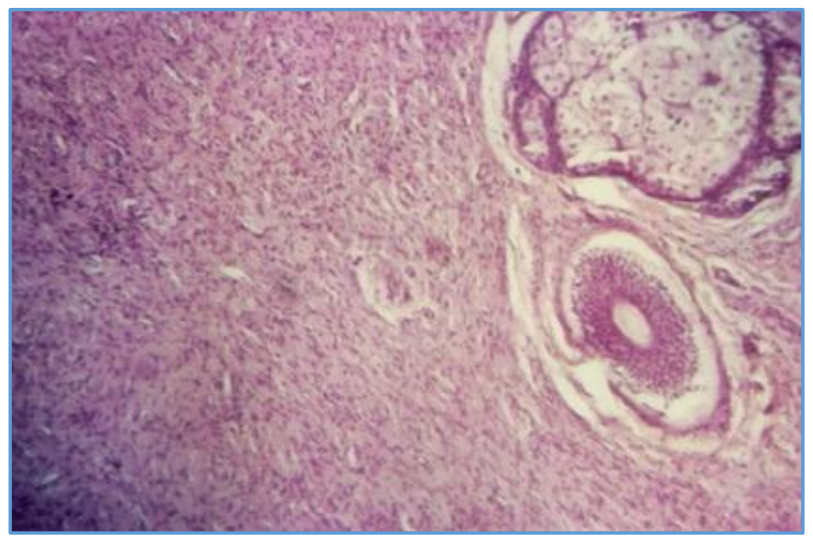

Figure 14(b). Histopathology of Neurofibroma showing thin wavy nerve fibres

\section{DISCUSSION}

The reporting of the skin tumours of head \& neck were more by the females (54\%) compared to males (46\%) probably because of their cosmetic awareness. The highest age incidence observed in this study was in the fifth decade (23\%) followed by sixth \& seventh decade (21\%) similar to the study of Vaibhav Bari et al.(2) Tumours such as epidermal nevus, nevus sebaceous, neurofibroma occur in childhood (23\%) and these need awareness among the parents to bring the children at an early age. Mostly were benign tumours (88\%) in our study. $68.4 \%$ and $31.6 \%$ were the incidences of benign and malignant tumours in the study done by Har- Shai et al(3) Acrochordons is the most common tumour (15\%) in our study. Study of Thappa DM et al with the study group of 35 patients, $62.8 \%$ (22 patients) had DM.(4) In our study, among 15 patients, $6(40 \%)$ had diabetes mellitus. In this study, all the cases reported with seborrhoeic keratosis were above forty years of age as in the study of Yeatman et al.(5) According to Mackie et al, the males \& females are equally affected with seborrhoeic keratosis.(6)

In this study, male outnumbered the female. A study conducted by Vidaurida la Cruz $\mathrm{H}$ et al, reported $7.9 \%$ of epidermal nevus syndrome in 443 patients with epidermal nevi.(7) No case of epidermal nevus syndrome was reported out of 6 cases of epidermal nevus. Out of seven cases with basal cell carcinoma, Nodulo-ulcerative was the commonest type seen in this study similar to the study conducted by
Christensen LJ et al(8) Rare case like xeroderma pigmentosum with squamous cell carcinoma was encountered in a female child. In this study, punctum was not seen in $50 \%$ of the 12 patients with histologically confirmed epidermal cysts which correlates well with Chandrasekaran V et al study.(9) Chang Geng et al, reported $83 \%$ of the cases among 104 cases developed before 10 years in contrast to all the cases of nevus sebaceous presented at birth in this study.(10) Females outnumbered the males with keloid in our study similar to Bayat et al study.(11) and one female case had positive family history. The age of occurrence of pyogenic granuloma was in third and fifth decade in all the cases which is similar to Hessa Al Wayli et al study. (12)

\section{CONCLUSION}

Thus, the study of skin tumours is perhaps more intriguing, fascinating, challenging at times. Hence, by clinical information, gross and histological features, definitive diagnosis can be made \& treated accordingly.

\section{REFERENCES}

[1] Seldon REJ. Histological typing of skin tumors. In: International classification of tumors. Geneva: WHO 1974.

[2] Bari V, Murarkar P, Gosavi A, et al. Skin tumourshistopathological review of 125 cases. Indian Medical Gazette 2014:418-27.

[3] Har-Shai Y, Hai N, Taran A, et al. Sensitivity and positive predictive values of presurgical clinical diagnosis of excised benign and malignant skin tumours: a prospective study of 835 lesions in 778 patients. Plast Reconstr Surg 2001;108(7):1982-9.

[4] Thappa DM. Skin tags as markers of diabetes mellitus: an epidemiological study in India. J Dermatol 1995;22(10):729-31.

[5] Yeatman JM, Kilkenny M, Marks R. The prevalence of seborrhoeic keratoses in an Australian population: does exposure to sunlight play a part in their frequency? Br J Dermatol 1997;137(3):411-4.

[6] Mackie RM. Epidermal skin tumours. In: Champion RH, Burton JL, (edtr.) Oxford Blackwell scientific publications, 1992:1459-559.

[7] Vidaurri-de la Cruz H, Tamayo-Sánchez L, DuránMcKinster C, et al. Epidermal nevus syndromes: clinical findings in 35 patients. Pediatric Dermatol 2004;21(4):432-9.

[8] Christenson LJ, Borrowman TA, Vachon CM, et al. Incidence of basal cell and squamous cell carcinomas in a population younger than 40 years. JAMA 2005;294(6):681-90.

[9] Chandrasekaran V, Parkash S, Raghuveer CV. Epidermal cyst-a clinico-pathological \& biochemical study. Postgrad Med J 1980;56(662):823-7.

[10] Chen MJ, Chan HL, Kuan YZ. Nevus sebaceus-a clinicopathological study of 104 cases. Changgeng Yi Xue Za Zhi 1990;13(3):199-207.

[11] Bayat A, Arscott G, Ollier WE, et al. Keloid disease: clinical relevance of single versus multiple site scars. $\mathrm{Br}$ J Plast Surg 2005;58(1):28-37.

[12] Hessa AW, Hezekiah MA. Pyogenic granuloma among Saudi females in an out-patient dental clinic. Saudi Dental Journal 2006;18(2). 